\title{
Workplace Spirituality, Organizational Learning Capabilities and Mass Customization: An Integrated Framework
}

\author{
Anant Deshpande \\ State University of New York Empire State College, Center for Distance Learning \\ 113 West Avenue, Saratoga Springs, NY 12866, USA \\ Tel: 1-956-750-0079_E-mail: Anant.Deshpande@esc.edu
}

Received: December 27, 2011

Accepted: January 29, 2012

Published: March 1, 2012

doi:10.5539/ijbm.v7n5p3

URL: http://dx.doi.org/10.5539/ijbm.v7n5p3

\begin{abstract}
In today's world organizations strive to achieve competitive advantage. To this end, mass customization (MC) as a source of competitive advantage has generated a lot of interest. Gap however exists in terms of exploring factors enabling the successful development of MC. The current study examines the role of organizational learning capabilities in the development of MC. In addition workplace spirituality has been known to influence organizational learning capability. Workplace spirituality also impacts overall employee as well as organizational outcomes and practices. The goal of the study is to explore the linkages between the dimensions of workplace spirituality, organizational learning capability and MC. Based on a comprehensive literature review, a theoretical framework and propositions are derived. The findings are expected to provide guidance for firms to effectively develop MC practices.
\end{abstract}

Keywords: Mass Customization, Organizational learning capability, Workplace spirituality

\section{Introduction}

Mass customization (MC) strategy, since its inception in late 1980s, has received much attention (Chu, Cheng \& Wu, 2006; Fogliatto \& Silveira, 2008; Helo, Xu, Kyllönen \& Jiao, 2010; Jiao, Ma \& Seng, 2006; Schentler, 2009; Wong \& Eyers, 2011). The main aim of MC is to provide customers with required products or services at high volumes, based on customer specifications and reasonably low costs (Silverira, Borenstein \& Fogliatto, 2001). Despite the increasing amount of attention paid to MC practices by practitioners and academicians to the entire process of MC, failures in effectively implementing MC strategies still exist (Broekhuizen \& Alsem, 2002; Kakati, 2002; Pine, Victor, \& Boynton, 1993; Selladurai, 2004).

One of the major reasons of the failure is the lack of understanding of the uniqueness in development of MC. Practitioners have found that development and implementation of MC practices is different from the traditional techniques such as TQM, and continuous improvement (Huang, Kristal \& Schroeder, 2008; Selladurai, 2004). It is this difference that prompts researchers to look deeper in the strategy and help practitioners develop mass customization strategies (Gilmore \& Pine, 1997; Lau, 1995; Svensson \& Barford, 2002). To this end, researchers have been urged to investigate the antecedents and individual aspects of MC practices with a view of providing managers guidance on development and implementation of MC practices (Gilmore \& Pine, 1997; Huang et al., 2008; Lau, 1995; Svensson \& Barford, 2002).

The important role of organizational learning capability has been documented previously in the development of mass customization practices (Kotha, 1996). For instance, the development of learning perspective is recommended for mass customizers (Pine II, Peppers, Rogers, 1995). This would further help organization achieve sustainable competitive advantage (Pine II et al., 1995). Lack of developing learning relationships have been cited as a major drawback in mass customization strategy of Nissan which resulted in escalation of costs and loss of quality and flexibility (Hart, 1996). Furthermore, as pointed out by Anzanello and Fogliatto (2007), to produce new models with changing customer demands, the workers need to develop learning capabilities and learn from previous models to derive new innovative models. This is required to prevent quality losses in initial stages of production. However despite the recognition of the importance of organizational learning capabilities in mass customization context research by and large has failed to systematically investigate specifically how the 
individual dimensions of organizational learning capability impacts mass customization. Furthermore given the important role organizational learning capability in development of MC it becomes critical to also examine how organizational learning capability can be developed. Workplace spirituality has been widely known in management literature to enhance organizational learning capability (Krishnakumar \& Neck, 2002; Kolodinsky, Giacalone, \& Jurkiewicz, 2008; Nur \& Organ, 2008; Sue, 2002). Despite this recognition literature is somewhat scattered and a systematic investigation of the linkages between specific dimensions of workplace spirituality and organizational capability is lacking.

Taken together the investigation of these linkages will give managers a perspective on the development of MC practices. In addition, the results will be further interesting because despite the fact that there have been isolated instances where researchers have linked workplace spirituality to OM concepts such as TQM (Marques, Allevato, $\&$ Holt, 2008) OM researchers in general and more specifically MC researchers have thus far neglected the role of workplace spirituality in unified MC context. Based on the above we seek to investigate the following:

- What are the relationships between the dimensions of workplace spirituality, organizational learning capabilities and mass customization?

\section{Contributions of the Study}

The study offers three major contributions. First, the major contributing factor of the study is to provide an overarching framework to the managers by exploring the linkages between dimensions of workplace spirituality, organizational learning capabilities and MC practices. As mentioned previously, this framework is critical as the lack of understanding of $\mathrm{MC}$ at all levels and lack of understanding of issues of implementation of $\mathrm{MC}$ has been widely highlighted (Selladuria, 2004; Duray,Ward, Milligan \& Berry, 2000). The approach is different from previous studies in that individual dimensions of mass customization are considered and their linkages amongst each other are explored.

Second, as pointed out by variety of strategic management researchers that despite the growth of organizational learning capability literature, there is still a need to understand what factors contribute toward enhancement of learning capability(Chen, 2005; Cyert \& March 1963; Prahalad \& Hammel, 1994). In addition, authors in the area of learning capability have pointed out that discrepancies still exist in selection of measures of organizational learning capability (Easterby-Smith, Crossan \& Nicolini, 2000; Lyles \& Easterby-Smith, 2003). Researchers have also debated over the critical dimensions of learning capabilities and lack of agreement still exists (Easterby-Smith et al., 2000; Gómez, Lorente, \& Valle-Cabrera, 2005; Lyles \& Easterby-Smith, 2003). The current study also adds to this stream by exploring the dimensions of organizational learning capability. In addition the study also investigates the linkages between the dimensions of organizational learning capability as recommended by Gómez et al. (2005). Furthermore despite the growing usage of learning capability in OM literature, researchers have failed to clearly study the linkages between critical learning capability dimensions and their impact on organizational practices such as MC or vice versa. This is relevant because exploring the linkages would help managers gain an insight on ways to enhance the organizational pratices such as MC. The study also seeks to address this issue.

Third, as pointed out by Krahnke, Giacalone and Jurkiewicz. (2003, p. 398) "further and important to the organizational literature as a whole, the study of workplace spirituality must be placed within the context of multidisciplinary research, illustrating how it fits within the broader mainstream research." This is also highlighted by other workplace spirituality researchers (Adawiyah, Shariff, Saud, \& Mokhtar, 2011; Dean, 2003; Dean, Fornaciari \& McGee, 2003; Krisnakumar \& Neck, 2002; Sheep, 2006; Tischler, Biberman \& Altman, 2007). In support to call made by various researchers in workplace spirituality literature the current study seeks to integrate the concept of workplace spirituality within the MC context in the OM literature thereby addressing one of the important demands in workplace spirituality stream of literature.

\section{Literature Review}

\subsection{Workplace Spirituality}

The last decade has seen a rise in the literature on the topic spirituality in the workplace (Altaf \& Awan, 2011; Dean, 2003; Kanter, 1982; King \& Crowther, 2004; King \& Nicol, 1999; Kinjerski \& Skyrpnek, 2004; Milliman, Czaplewski \& Ferguson, 2003; Neal \& Biberman, 2003; Tischer et al., 2007). Workplace spirituality has been defined as "Workplace spirituality is a framework of organizational values evidenced in the culture that promotes employees' experience of transcendence through the work process, facilitating their sense of being connected to others in a way that provides feelings of completeness and joy (Giacalone \& Jurkiewicz, 2003, p. 
13). A literature review was carried out to identify the dimensions of workplace spirituality and is shown in Table 1.

\section{Insert Table 1 here}

Workplace spirituality is associated with attaining connection with oneself, others, and workplace environment. Workplace spirituality is further related to self-actualization. Tishcer (1999) considers Abraham Maslow's hierarchy of needs model and identifies the highest need as self-actualization connected to spirituality. Butts (1999) mentions that the idea of spirituality in the workplace is important and identifies dimensions of spirituality such as optimal human development, the art of transcendence and spiritual psychologies. Burack (1999), with the help of different case studies such as Tom's of Maine, Hewlitt Packard, and the Ford Motor Company, highlights the importance of workplace spirituality as one of the important themes in the development of the organization. As pointed out by Krishnakumar and Neck (2002), organizations who help employees or who are willing to provide "individual encouragement" and assist the employee in achieving spirituality, gain better performance. Another interpretation would be that "spiritual employees" lead to better organizational performance. Based on the Table 1 the major dimensions of workplace spirituality are: organizational norms and connectedness. A brief discussion of each is presented next.

\subsubsection{Organizational norms}

Organizational norms can be described as set of guidelines related to behavior which are agreed upon by managers and decision makers (Balthazard, Cooke \& Potter, 2006). These guidelines are based on the firm specific organizational culture (Balthazard et al., 2006). Norms should be developed to promote supporting organizational values. In context of spirituality norms should be developed in such as manner that provides an employee with a spiritual growth at workplace. The norms should be based on enrichment and nourishment of individual wellbeing which will lead to enhanced motivation and overall performance (Sheep, 2006).

\subsubsection{Connectedness}

This dimension of workplace spirituality encompasses closeness with coworkers and overall organizational environment (Mitroff \&Denton, 1999). If the people feel a part of the community this will be exemplified by high commitment sharing and trust (King \& Crowther, 2004). This will further enhance communication channels. The feeling of connectedness further helps employee to work in a cordial and joyful environments (Dean, 2003). An organization where employees are connected with each other and overall organizational goals will have enhancement in overall performance.

\subsection{Organizational Learning Capability}

Organizational learning has been a centre of attraction for researchers for long time (Daft \& Weick, 1984; Huber, 1991; Senge, 1990). As pointed out by Huber (1991) Organizational learning involves forward and backward movement of knowledge along different levels. For instance, movement of knowledge occurs from individual level to group level to organizational level and vice versa. Thus organizational learning capability can be defined as processes which enable flow of knowledge. More specifically organizational learning capabilities are those processes, characteristics or structures which enhance sharing, acquisition and adequate utilization of knowledge within or outside the organization (Cheva, Alegra \& Lapiedra, 2007). As pointed out by Slater and Narvekar (1995) it becomes critical to consider organizational learning capability as multidimensional construct. The current study conducts a literature review to identify critical dimensions of organizational learning capability. Based on the literature review indicated in Table 2 it was found that openness and experimentation and knowledge transfer were the critical dimensions of organizational learning capability. A brief discussion of each is presented next.

\section{Insert Table 2 here}

\subsubsection{Openness \& Experimentation}

The concept of openness \& experimentation refers to the ability of the firm to promote and build a climate which is receptive to accepting new ideas and thoughts and allows individual knowledge to be constantly expanded upon without any restrictions (Akgun, Keskin, Byrne, \& Aren, 2007). Some of the aspects such as lack of favoritism, promotion of cultural-functional diversity, equal treatment of employees \& availability of appropriate information to employees promote a climate of openness \& experimentation (McGill, Slocum \& Lei, 1992).

\subsubsection{Knowledge Transfer}

Knowledge transfer deals with learning caused by sharing of experience between different organizational units (Darr, Argote \& Epple, 1995). It has been evident that firms which are better equipped in handling knowledge 
transfer activities are better able to survive in the competitive market (Tsai, 2002). Knowledge transfers are of two types: Knowledge transformation and knowledge transmission (Hamilton, 2005). Knowledge transformation and knowledge transmission are fundamentally different. The main difference is in the fact that knowledge transformation involves the conversion of knowledge according to the needs of the concerned organizational unit however knowledge transmission involves transfer of information based on experience of a firm to another firm. Knowledge transfer can be achieved by formation of communication network, forming cross functional teams, and arranging discussions (Hamilton, 2005)

\subsection{Mass Customization Capabilities}

There have been plenty of studies identifying different dimensions of mass customization. For instance the study by Selladurai (2004) considers standardization approaches including process, product, procurement and partial standardization, to be the key elements of mass customization. Blecker and Abdelkafi (2006) recognize the importance of purchasing, production and internal logistics, and product development as important elements of mass customization. A study by Su, Chang and Ferguson (2005), recognizes postponement as a key dimension of mass customization. Customer sensibility, process amenability, competitive environment and organizational readiness have been identified as critical elements of mass customization (Hart, 1995). Jiang, Lee and Seifert (2006) state that mass customization consists of two opposite extremes such as mass production and customization. Studies by Dobrescu and Reich (2003) clearly mention the importance of modularity from mass customization perspective. A conceptual typology is developed which helps in identifying firms practicing mass customizations from an operations perspective (Duray et al., 2000). The authors found that involvement of customer and responding to customer needs in addition to product/process modularity are key to success of mass customization (Duray, 2000). Modularity and customer responsiveness have been identified as important dimensions for mass customization by other studies (Arnheiter \& Harren, 2005; Schmenner \& Tatikonda, 2005; Tseng \& Jiao, 2003; Voordijk, Meijboom \& Haan, 2006). As mentioned above, the key dimensions agreed by most studies are postponement, modularity and customer responsiveness. For the purpose of the study, each of these dimensions was used and a detailed discussion of each is presented next.

\subsubsection{Modularity}

Modularity refers to flexibility in process or product in terms of different combinations of components or subassemblies. In a module, the structural elements are connected powerfully to member components of their units (Baldwin \& Clark, 2000). In addition, the connection between components of different units is weak (Baldwin \& Clark, 2000). The process modularity involves creating flexibility in the process of manufacture and production of a product in semi-completed form. The products might be different in terms of types of operations and forms (Selladurai, 2004). It has been mentioned that introduction of modularity has tremendous benefits for an organization. Some of the benefits include reduction in inventory costs and reduction of time to markets (Fisher, Ramdas, \& Ulrich, 1999; Thyssen, Isaelsen \& Jorgensen, 2006).

\subsubsection{Postponement}

Postponement deals with flexibility and allows for forward movement of operations to a much later point of the supply chain (Su et al., 2005). Different forms of postponement include time postponement (TP) and form postponement (FP). Time postponement or the make to order approach involves waiting for customer orders (Prasad, Tata \& Madan, 2005; Su et al., 2005; Zhang \& Efstathiou, 2006). This dimension of postponement gives priority to customer orders and delays the manufacturing and shipping until customer orders have been received (Su et al., 2005). Form postponement deals with delivery of product in a semi-finished form (Graman \& Magazine, 2006; Su et al., 2005). The product is stocked in the final assembly where, depending on the customer orders, the product is customized (Su et al., 2005).

\subsubsection{Customer Responsiveness}

The customer is an important link in implementing MC strategy. The goal of any MC strategy is to provide customers with desired quantities at a desirable cost. Customer responsiveness involves communicating and maintaining a relationship with the customer that will help an organization understand the needs of the customer and respond in a timely manner (Selladurai, 2004).

\section{Theoretical Framework}

\subsection{Organizational norms, Openness and Experimentation and Knowledge Transfer}

Organizational norms specify the actions to be carried out in a specific situation (Christenson, Hougland, Ilvento \& Shepard, 1988). Organizational norms have been found to control and have an impact on the behavior and emotions of the employee in a positive as well as a negative manner. For instance, if the norms of the 
organization are such that they encourage opposition culture, then employees might express more negative emotions (Cooke \& Scuzmal, 1987). Formation of norms would enhance a firms ability to regulate and control emotions and lead to enhancement of an atmosphere of openness and experimentation. It has been mentioned that creating resources through norms has been a positive way to regulate openness and experimentation in groups (Brown \& Dugaid, 2000; Scott \& Brown, 1999). In addition it has been well known that if a firm develops norms to form a climate of openness and experimentation this has many benefits. For instance, communication is enhanced, a close relationship is developed between members and the transfer of knowledge is increased (Brown \& Dugaid, 2000; Riege, 2007; Scott \& Brown, 1999; Sharifuddin \& Fytton, 2007; Yih-Tong Sun, \& Scott, 2005). When a firm maintains clear cultural norms and communication norms knowledge transfer and sharing is enhanced. For instance, as mentioned by (Heidi \& Miner, 1992) cooperative norms are beneficial in knowledge sharing, and proper use of power. Thus we propose:

Proposition 1: Organizational norms have a positive influence on knowledge transfer by developing a climate of openness and experimentation

\subsection{Organizational Norms, Connectedness and Knowledge Transfer}

If firm's organizational norms are designed in such a manner that connectedness is promoted and individuals are allowed to express themselves freely there will be display and sharing of positive emotions. As mentioned by Durand and Huy (2007) allowing individuals to freely express their emotions has a positive influence on knowledge transfer, enhanced energy level at work and allows for better interactive channel formation. It can be said that if employees feel a sense of connectedness with each other and the organization they would actively involve in knowledge sharing, transfer and knowledge accumulation activities. Firm's knowledge creation capabilities involve activities such as assimilation, synthesizing and sharing various creative ideas, exploitation of the ideas. If a sense of connectedness develops between employees this will allows them to display their emotions freely and have a greater interest in sharing the knowledge created using assimilation processes. Based on the above we propose:

Proposition 2: Organizational norms have a positive influence on knowledge transfer by developing a sense of connectedness between employees and organization

\subsection{Openness and Experimentation, Knowledge transfer and Modularity}

An atmosphere of openness \& experimentation creates synergistic environment. A climate of openness and experimentation would also help in effective formation of communication network between different member components of the organizations. This would help in effective coordination of appropriate information which would further lead to effective knowledge transfer amongst employees. The culture of openness and innovation provides a platform for a firm to share and develop new ideas (Akgun et al., 2007). In addition, the open atmosphere within the firm provides the opportunity to expand, rectify and widen the knowledge. The openness and experimentation in an organization encourages departments to seek solutions from within and outside to facilitate existing processes (Akgun et al., 2007). If the environment within the firm promotes experimentation, departments will be motivated to engage in knowledge transfer and try out new combinations which would in turn enhance modularization of product and process. In addition if the organization is active in experimentation and willing to seek changes in ideas and change the existing set up, knowledge transfer would help the firm achieve its objective. A synergy is formed as a result of atmosphere of openness and the employee develops the sense of initiative. Because of an open environment, workers will share experiences with other workers thereby facilitating internal transfer of tacit knowledge. This would further help the workers conceptualize problem, take experiences into consideration and generate solutions to problems (Bou-Llusar\& Segarra-Ciprés, 2006). Knowledge transfer between members of an organization will help enhance the creation of ideas and provide an insight into different combinations or subassemblies. Because of an open environment there will be sharing of both tacit and explicit knowledge between employees. This will help in development of flexible design and enhance modularity in product and process design. Based on the above we propose:

Proposition 3: Openness and experimentation has a positive impact on modularity via Knowledge transfer

\subsection{Modularity, Postponement and Customer responsiveness}

In simple terms, postponement deals with delaying tasks such as storing products in semi-complete forms until the last minute (Li, B.Nathan, T.Nathan, Rao, 2006). Depending on the needs of the customers, products are then delivered, thereby reducing holding costs such as inventory costs or handling and logistics cost. Modularization of the products, as mentioned, before involves dividing products into small modules (Yang, Burns \& Backhouse, 2004). This aids in postponement, as based on the customer demands, and modules can be converted into 
products and delivered to the customer. Modularity, in other words, has been identified as an essential enabler along with other processes such as manufacturing, and logistics (Yang et al., 2004). Researchers have urged organizations implementing postponement to study the modularization processes and obtain benefits by implementation of modular processes or products (Feitzinger \& Lee, 1997).

Postponement has been commonly portrayed in the literature as a source of reduction of inventory and improved customer responsiveness (Lee \& Tang, 1997; Swaminathan \& Tayur, 1998). Customer demands have become variable. Organizations, in order to sustain market position and retain the customers, turn to strategies such as postponement. The strategy of postponement is implemented by an organization to meet customer needs and reduce lead time (Aviv \& Federgruen, 2001). Depending on the customer needs, the strategy of postponement can either facilitate delays in process or form of the product ( $\mathrm{Li}$ et al., 2006). This leads to enhanced flexibility and improved customer responsiveness (Van Hoek, Voss \& Commandeur, 1999). Accordingly we posit:

Proposition 4: Modularity has a positive impact on postponement

Proposition 5: Postponement has a positive impact on customer responsiveness

\subsection{Modularity\& Customer responsiveness}

The modular product design enables firms to develop independent modules and flexibility in assembly of modules to form new products (Sanchez, 1995). In addition, customer loyalty and responsiveness might also be seriously affected if there is longer delivery time or lead time (Handfield \& Pannesi, 1995). In case of defective delivery, modularization offers a benefit in terms of customer responsiveness. The customer responsiveness is enhanced using modularity in product design as organizations can quickly work on the defective modules and provide customers with improved products (Karmarkar \& Kubat, 1987). All of the above lead us to the following:

Proposition 6: Modularity is positively related to enhanced customer responsiveness

Figure 1 depicts all the proposed relationships mentioned above.

\section{Insert Figure 1 here}

\section{Discussion and Managerial Implications}

In the current decade where the economy is marked with organization's dealing with changes in customer demands, it becomes imperative to have knowledge of effective development of MC. The motivation to carry out this study was the fact that even though organizations implement MC, there has been evidence of failure of MC strategies. This study is specifically designed to provide managers with an overarching framework for effective development of MC. The purpose is achieved by proposing an extended framework identifying potential linkages. The uniqueness of the study, as mentioned before, is in the fact that no study has so far investigated the relationships between dimensions of workplace spirituality, organizational learning, and MC.

On a macro level the exploration of positive linkage between dimensions of workplace spirituality and organizational learning capability addresses two major issues. First, there is some evidence of connection between workplace spirituality and improved organizational learning capability (Kolodinsky, Giacalone, \& Jurkiewicz, 2008; Krishnakumar \& Neck, 2002; Nur \& Organ, 2008; Sue, 2002). However to the best of our knowledge no study has explored the linkages between individual dimensions of workplace spirituality and organizational learning capability. The current study offers a valuable insight on these linkages. In the process the study also identifies critical dimensions of learning capabilities which is important and must be done to further the research in organizational learning capability (Prieto \& Ravilla, 2006). Second, the study looks at these linkages in MC context. This becomes important because MC literature has predominantly focused on technical issues (Duray, 2006) and as pointed out by (Hart, 1995; Huang et al., 2008; Kakati, 2002; Kotha, 1995) investigation of soft issues in development of MC processes is extremely important and deserves attention.

On a micro level, the positive linkages between organizational norms, connectedness, openness and experimentation and knowledge transfer offer interesting insights. The importance of norms in psychology literature is evident (Aquino, Douglas \& Martinko, 2004; Ehrhart \& Naumann, 2004). However, it has been recognized that there has been a general lack of integration of organizational norms in theoretical frameworks in management literature (Nilsson, Borgstede \& Biel, 2004). The current study can be seen as a step in this direction. The positive association of organizational norms with knowledge transfer would further encourage managers to actively set up norms specifically to regulate knowledge sharing and transfer across the entire organization. It is also recommended that managers would be advised to involve all categories of employees in formulation of MC strategies and development of knowledge based systems. Developing norms which promote 
employees connectedness at all levels within organization would help employees understand each others feelings, allow people to develop feeling of closeness and remove the fear of reprisal and facilitate knowledge transfer which would have a positive impact on MC.

Knowledge management has been identified as a key source of organizational success (Prasad, 2001). Knowledge has been seen as a driver of company life and knowledge of people is seen as a wealth of the organization. One of the important pillars on which knowledge management rests is learning (Mohamed, Stankosky \& Murray, 2004). Learning will occur if individuals are open to suggestions and shared visions. Positive linkage between organizational norms and knowledge transfer would encourage managers to focus on the development of organizational norms. For instance, norms such as establishing strong communication networks will further enhance the effective sharing of information and knowledge. Socialization is important to communicate norms in an organization (Meyor \& Allen, 1990). Thus managers are recommended to focus both on communication network and socialization aspect of members to effectively communicate the norms within organization. Managers would be advised to invest in socialization outlets such as informal gatherings, meetings, and get-togethers to promote socialization. The positive association between organizational norms and knowledge transfer will further motivate managers to inculcate the network formation which would facilitate in achieving optimum results in terms of improved organizational learning by effective scanning of the environment and sharing of required information. Implications for managers thus include formation and organize communication network channels, investing in team bonding and relationships to communicate norms and enhance knowledge transfer.

One recommendation to managers would be to develop an atmosphere with openness and experimentation which will enhance knowledge transfer and would facilitate managers in enhancing product and process modularity. Managers would be recommended to engage in knowledge sharing activities as they would facilitate in strategy making and decision formation from a modularity perspective.

The current study provides an analysis of critical dimensions of MC. In the process it also explores the linkages between dimensions of $\mathrm{MC}$ and addresses relevant gaps in the literature. Modularity was identified as a critical dimension of MC. As pointed out by (C.Pan, G. Pan, Chen, \& Hsieh, 2007) there is a paucity of research on investigating factors which a firm can focus on while implementing modularity of product or processes during capability development. This study provides an insight on factors such as knowledge transfer critical for the development of modularity during capability development processes and recommends managers to develop and focus on knowledge transfer mechanisms. Modularity and postponement were also proposed to have a positive impact on impact on customer responsiveness. Manufacturers today face immense pressure from customers to meet specific requirements. From a supply chain context, by engaging in practices such as modularity and postponement managers would develop highly flexible and responsive supply chains which would further enhance customer responsiveness. A recommendation to managers would be develop integration channels with customers this would also enhance customer responsiveness.

\section{Conclusion, Limitations and Future Research}

The goal of achieving sustainable competitive advantage by building competencies and resources has been central to a firm's strategy. The role and popularity of MC in this context remains unquestioned. However there exists a need to answer some unanswered questions. As pointed out by Da Silveria, Borenstein and Fogliatto (2001) much of research in MC has focused in explaining the importance of MC and its consequences. There is little evidence in terms of exploration of development of MC (Da Silveria et al., 2001). Furthermore prior research in the area of $\mathrm{MC}$ has recognized the importance of organizational learning capability in MC perspective. However, detailed exploration of linkages is lacking in literature. In addition despite the recognized importance of Workplace spirituality in management literature a systematic investigation of impact of workplace spirituality on OM practices and particularly MC context is lacking. Hence a study of this nature is warranted.

The major limitation of the study is that it is theoretical in nature. The goal of the researchers is to conduct an empirical research to add validity to the findings. Future research should identify additional dimensions of workplace spirituality include them in the current framework. The impact of other important dimensions of organizational learning capability such as managerial commitment and culture can also be investigated. As pointed out Goleman (1998) organizations can no longer neglect the human abilities and emotions of the employees within the organizations. From an MC perspective the use of emotional capability of the organization and its impact on MC capabilities can be investigated. Future research in MC can explore the linkages between knowledge creation practices, mass customization dimensions and the impact on other competitive capabilities 
such as time to market. In addition, the impact of variables such as firm size, firm structure and the firm positioning in supply chain should be investigated on the above mentioned linkages.

\section{References}

Adawiyah, W., Shariff, M., Saud, M., \& Mokhtar, M. (2011). Workplace Spirituality as a Moderator in the Relationship between Soft TQM and Organizational Commitment. International Journal of Business \& Social Science, 2(10), 93-100.

Akgün, A. E., Keskin, H., Byrne, J. C., \& Aren, S. (2007). Emotional and learning capability and their impact on product innovativeness and firm performance. Technovation, 27(9), 501-513. http://dx.doi.org/10.1016/j.technovation.2007.03.001

Altaf, A., \& Awan, M. (2011). Moderating Affect of Workplace Spirituality on the Relationship of Job Overload and Job Satisfaction. Journal of Business Ethics, 104(1), 93-99. http://dx.doi.org/10.1007/s10551-011-0891-0

Anzanello, M. J., \& Fogliatto, F. S. (2007). Learning curve modelling of work assignment in mass customized assembly lines. International Journal of Production Research, 45(13), 2919-2938. http://dx.doi.org/10.1080/00207540600725010

Aquino, K., Douglas, S., \& Martinko, M. J. (2004). Overt Anger in Response to Victimization: Attributional Style and Organizational Norms as Moderators. Journal of Occupational Health Psychology, 9(2), 152-164. http://dx.doi.org/10.1037/1076-8998.9.2.152

Arnheiter, E.D., \& Harren, H. (2005). A typology to unleash the potential of modularity. Journal of Manufacturing Technology Management, 16(7), 699-711. http://dx.doi.org/10.1108/17410380510619923

Ashmos, D., \& Duchon, D. (2000). Spirituality at work. Journal of Management Inquiry, 9,134-145. http://dx.doi.org/10.1177/105649260092008

Aviv, Y., \& Federgruen, A. (2001). Design for postponement: a comprehensive characterization of its benefits under unknown demand distributors. Operations Research, 49(4), 578-98. http://dx.doi.org/10.1287/opre.49.4.578.11229

Badrinarayanan, V., \& Madhavaram, S. (2008). Workplace spirituality and the selling organization: A conceptual framework and research propositions. Journal of Personal Selling \& Sales Management, 28(4), 421-434. http://dx.doi.org/10.2753/PSS0885-3134280406

Baldwin, C.Y., \& Clark, K.B. (2000). Design Rules. MIT Press, Cambridge, MA.

Balthazard, P., Cooke, R., \& Potter, R.E. (2006). Dysfunctional culture, dysfunctional organization: Capturing the behavioral norms that form organizational culture and drive performance. Journal of Managerial Psychology, 21(8), 709-732. http://dx.doi.org/10.1108/02683940610713253

Becker, M. C., \& Zirpoli, F. (2007). Organizing Open Innovation: The Role of Competences, Modularity, and Performance Integration. Academy of Management Proceedings, 1-6.

Bhatnagar, J. (2006). Measuring organizational learning capability in Indian managers and establishing firm performance linkage: An empirical analysis. The Learning Organization, 13(5), 416-433. http://dx.doi.org/10.1108/09696470610679965

Blecker, T., \& Abdelkafi, N. (2006). Complexity and variety in mass customization systems: analysis and recommendations. Management Decision, 44(1), 908-929. http://dx.doi.org/10.1108/00251740610680596

Bou-Llusar, J.C., \& Segarra-Ciprés, M. (2006). Strategic knowledge transfer and its implications for competitive advantage: an integrative conceptual framework. Journal of Knowledge Management, 10(4), 142-154. http://dx.doi.org/10.1108/13673270610679390

Broekhuizen, T.L., \& Alsem, K.J. (2002). Success Factors for Mass Customization: A Conceptual Model. Journal of Market-Focused Management, 5, 299-376.

Brown, J.S., \& Duguid, P. (2000). The Social Life of Information. Harvard Business School Press: Boston, MA.

Burack, E., H. (1999). Spirituality in the work place. Journal of Organizational Change Management, 12(4), 280-91. http://dx.doi.org/10.1108/09534819910282126

Butts, D. (1999). Spirituality at work: an overview. Journal of Organizational Change Management, 12(4), 328-331.http://dx.doi.org/10.1108/09534819910282162 
Chen, G. (2005). Management Practices and Tools for Enhancing Organizational Learning Capability. SAM Advanced Management Journal, 70(1), 4-35.

Cheva, R., Alegre, J., \& Lapiedra, R. (2007). Measuring organisational learning capability among the workforce. International Journal of Manpower, 28(3/4), 224-242. http://dx.doi.org/10.1108/01437720710755227

Christenson, J.A., Hougland, J. G., Ilvento, T. W., \& Shepard, J.M. (1988). The 'Organization Man' and the Community: The Impact of Organizational Norms and Personal Values on Community Participation and Transfers. Social Forces, 66(3), 808-827. http://dx.doi.org/10.1093/sf/66.3.808

Chu, C., Cheng, C., \& Wu, C. (2006). Applications of the Web-based collaborative visualization in distributed product development. Computers in Industry, 57, 272-282. http://dx.doi.org/10.1016/j.compind.2005.12.004

Cooke, R. A., \& Szumal, J. L. (1987). Interpreting the cultural styles measured by the OCI' in Organizational Culture Inventory. In R. Cooke (Ed.), Level V, Leader's.

Crossan, M. M., Lane, H.W., \& White, R.E. (1999). An organizational learning framework: from intuition to institution. Academy of Management Review, 24, 522-537. http://dx.doi.org/10.5465/AMR.1999.2202135

Cyert, R. M., \& March, J. (1963). A behavioral theory of firm. Englewood Cliffs, NJ: Prentice-Hall.

Da Silveira, D. Borenstein,M., \& Fogliatto, F.S. (2001). Mass customization: literature review and research directions. International Journal of Production Economics, 72, 1-13. http://dx.doi.org/10.1016/S0925-5273(00)00079-7

Daft, R.L., \& Weick, K. E. (1984). Toward a Model of Organizations as Interpretation Systems. Academy of Management Review, 9, 284-295. http://dx.doi.org/10.5465/AMR.1984.4277657

Darr, E.D., Argote, L., \& Epple, D. (1995). The acquisition, transfer, and depreciation of knowledge in service organizations: productivity in franchises. Management Science, 41(11), 1750-1762. http://dx.doi.org/10.1287/mnsc.41.11.1750

Dean, K. (2003). Research in spirituality, religion and work: walking the line between relevance and legitimacy. Journal of Organizational Change Management, 16, 167-189.

Dean, K.L., \& Safranski, S.R. (2008). No Harm, No Foul? Organizational Intervention in Workplace Spirituality. International Journal of Public Administration, 31(4), 359-371. http://dx.doi.org/10.1080/01900690701590751

Dean, L.K., Fornaciari, C.J., \& McGee, J.J. (2003). Research in Spirituality, Religion, and Work: Walking the Line between Relevance and Legitimacy. Journal of Organizational Change Management, 16(4), 378-395. http://dx.doi.org/10.1108/09534810310484145

DiBella, A.J., Nevis, E. C., \& Gould, J.M. (1996). Understanding organizational learning capability. Journal of Management Studies, 33(3), 361-379. http://dx.doi.org/10.1111/j.1467-6486.1996.tb00806.x

Dobrescu, G., \& Reich, Y. (2003). Progressive sharing of modules among product variants. Computer-Aided Design, 35(9), 791-806. http://dx.doi.org/10.1016/S0010-4485(02)00104-5

Durand. R., \& Huy, Q. (2007). Knowledge sharing in organizations: inviting ethics and emotion to the banquet. Academy of Management Proceedings, 1-5.

Duray, R. (2000). Mass customization origins: mass or custom manufacturing? International Journal of Operations and Production Management, 22(3), 314-328. http://dx.doi.org/10.1108/01443570210417614

Duray, R. (2006). Pursuing capabilities of flexibility and quality: financial performance implications for mass customisers. International Journal of Mass Customisation, 1, 260-271.

Duray, R., Ward, P.T., Milligan, G.W., \& Berry, W.L. (2000). Approaches to mass customization: configurations and empirical validation. Journal of Operations Management, 18(6), 605-625. http://dx.doi.org/10.1016/S0272-6963(00)00043-7

Easterby-Smith, M., Crossan, M., \& Nicolini, D. (2000). Organizational learning: debates past, present and future. Journal of Management Studies, 37(6), 783-796. http://dx.doi.org/10.1111/1467-6486.00203

Ehrhart, M.G., \& Naumann, S.E. (2004). Organizational Citizenship Behavior in Work Groups: A Group Norms Approach. Journal of Applied Psychology, 89(6), 960-974. http://dx.doi.org/10.1037/0021-9010.89.6.960

Fairholm. (1996). Spiritual leadership: Fulfilling whole-self needs at work. Leadership \& Organization Development Journal, 17, 11-17. 
Feitzinger, E., \& Lee, H. L. (1997). Mass Customization at Hewlett-Packard: The Power of Postponement. Harvard Business Review, 75,116-121.

Fisher, M., Ramdas, K., \& Ulrich, K. (1999). Component sharing in the management of product variety: a study of automotive breaking systems. Management Science, 45(3), 297-315. http://dx.doi.org/10.1287/mnsc.45.3.297

Fogliatto, F.S., \& Silveira, G. (2008). Mass customization: A method for market segmentation and choice menu design. International Journal of Production Economics, 111(2), 606-622. http://dx.doi.org/10.1016/j.ijpe.2007.02.034

Giacalone, R. A., \& Jurkiewicz, C.L. (2003). Toward a Science of Workplace Spirituality in R. A. Giacalone and C. L. Jurkiewicz (eds.) The Handbook of Workplace Spirituality and Organizational Performance M.E. Sharpe, Armonk, NY.

Gilmore, J., \& Pine, J. (1997). The four faces of mass customization. Harvard Business Review, 75, 91-101.

Goh, S.C., \& Richards, G.R. (1997). Benchmarking the learning capability of organizations. European Management Journal, 15(5), 575-583. http://dx.doi.org/10.1016/S0263-2373(97)00036-4

Goleman, D. (1998). Working with Emotional Intelligence. Bloomsbury Publishing: Soho Square, London.

Gómez, P. J., Lorente, J. J., Céspedes, C., \& Valle, R. (2004). Training practices and organisational learning capability. Journal of European Industrial Training, 28(2-4), 234-256.

Gómez, P.J., Lorente, J.J., \& Valle-Cabrera. (2005). Organizational learning capability: a proposal of measurement. Journal of Business Research, 58(6), 715-725. http://dx.doi.org/10.1016/j.jbusres.2003.11.002

Gotsis, G., \& Kortezi, Z. (2008). Philosophical Foundations of Workplace Spirituality: A Critical Approach. Journal of Business Ethics, 78(4), 575-600. http://dx.doi.org/10.1007/s10551-007-9369-5

Graman, G.A., \& Magazine, M.J. (2006). Implementation issues influencing the decision to adopt postponement. International Journal of Operations \& Production Management, 26(10), 1068-1083. http://dx.doi.org/10.1108/01443570610691076

Hamilton, M. K. (2005). The knowledge transformation process: the role of multidimensional uncertainty in strategy formulation. Academy of Management Proceedings, M1-M6.

Handfield, R.B., \& Pannesi, R.T. (1995). Antecedents of a leadtime competitiveness in make-to-order manufacturing firms. International Journal of Production Research, 33(2), 511-538. http://dx.doi.org/10.1080/00207549508930163

Harrington, W. J., Preziosi, R.C., \& Gooden, D.J. (2001). Perceptions of Workplace Spirituality among Professionals and Executives. Employee Responsibilities \& Rights Journal, 13(3), 155-163. http://dx.doi.org/10.1023/A:1014966901725

Hart, C.W. (1995). Mass customization: conceptual underpinnings, opportunities and threats. International Journal of Service Industry Management, 6(2), 36-45. http://dx.doi.org/10.1108/09564239510084932

Heide, J.B., \& Miner, S. (1992). The shadow of the future: Effects of anticipated interaction and frequency of contact on buyer-seller cooperation. Academy of Management Journal, 35(2), 265-291. http://dx.doi.org/10.2307/256374

Helo, P.T., Xu, Q.L., Kyllönen, S.J., \& Jiao, R.J. (2010). Integrated Vehicle Configuration System-Connecting the domains of mass customization. Computers in Industry, 61(1), 44-52. http://dx.doi.org/10.1016/j.compind.2009.07.006

Hirschhorn, L., Noble, P., \& Rankin, T. (2001). Sociotechnical systems in an age of mass customization. Journal of Engineering and Technology Management, $18(3-4), \quad 241-252$. http://dx.doi.org/10.1016/S0923-4748(01)00036-4

Huang, X., Kristal, M.M., \& Schroeder, R.S. (2008). Linking Learning and Effective Process Implementation to Mass Customization Capabilities. Journal of Operations Management, 26,714-729.

Huber, G.P. (1991). A theory of the effects of advanced information technologies on organizational design, intelligence and decision making. Academy of Management Review, 15(1), 47-71. http://dx.doi.org/10.5465/AMR.1990.4308227

Jiang, K., Lee, H.L., \& Seifert, R.W. (2006). Satisfying customer preferences via mass customization and mass production. IIE Transactions, 38(1), 25-38. http://dx.doi.org/10.1080/07408170500346386 
Jiao, J., Ma, O., \& Tseng, M.M. (2003). Towards high value-added products and services: mass customization and beyond. Technovation, 23(10), 809-821. http://dx.doi.org/10.1016/S0166-4972(02)00023-8

Kakati, M. (2002). Mass customization - needs to go beyond technology. Human Systems Management, 21, 85-93.

Kanter, R.M. (1982). The middle manager as innovater. Harvard Business Review, 21, 95-105.

Karmarkar, U.S., \& Kubat, P. (1987). Modular product design and product support. European Journal of Operational Research, 29(1), 74-82. http://dx.doi.org/10.1016/0377-2217 (87)90195-0

King S., \& Nicol D. (1999). Organizational enhancement through recogniztion of individual spirituality. Journal of Organizational Change Management, 12(3), 234-242. http://dx.doi.org/10.1108/09534819910274026

King, J., \& Crowther M. (2004). The measurement of religiosity and spirituality Examples and issues from psychology. Journal of Organizational Change Management, 17(1), 83-101. http://dx.doi.org/10.1108/09534810410511314

Kinjerski, V, M., \& Skrypnek, B. (2004). Defining spirit at work: finding common ground. Journal of Organizational Change Management, 17(1), 26-42. http://dx.doi.org/10.1108/09534810410511288

Kolodinsky, R., Giacalone, R., \& Jurkiewicz, C. (2008). Workplace Values and Outcomes: Exploring Personal, Organizational, and Interactive Workplace Spirituality. Journal of Business Ethics, 81(2), 465-480. http://dx.doi.org/10.1007/s10551-007-9507-0

Konz, G., \& Ryan, F. (1999). Maintaining an organizational spirituality: no easy task. Journal of Organizational Change Management, 12(3), 200-210. http://dx.doi.org/10.1108/09534819910273865

Kotha, S. (1995). Mass customization: Implementing the emerging paradigm for competitive advantage. Strategic Management Journal, 16(S1), 21-42. http://dx.doi.org/10.1002/smj.4250160916

Kotha, S. (1996). Mass-customization: A strategy for knowledge creation and organizational learning. International Journal of Technology Management, 11(7/8), 846-859.

Krahnke, K., R. A. Giacalone \& C. L. Jurkiewicz. (2003). Point Counterpoint: Measuring Workplace Spirituality. Journal of Organizational Change Management, 16(4), 396-405. http://dx.doi.org/10.1108/09534810310484154

Krishnakumar S., \& Neck, C. (2002). The "what","why" and "how" of spirituality in the workplace. Journal of Managerial Psychology, 17(3), 153-164. http://dx.doi.org/10.1108/02683940210423060

Lau, R. (1995). Mass customization: the next industrial revolution. Industrial Management, 37, 18-19.

Lee, H.L., \& Tang, C.S. (1997). Modeling the costs and benefits of delayed product. Management Science, 43(1), 40-53. http://dx.doi.org/10.1287/mnsc.43.1.40

Li, S., Nathan, B.R., Nathan, T.S., \& Rao, S, S. (2006). The impact of supply chain management practices on competitive advantage and organizational performance. Omega, 34(2), 107-124. http://dx.doi.org/10.1016/j.omega.2004.08.002

Lichtenthaler, U. (2009). Absorptive capacity, environmental turbulence, and the complementarity of organizational learning processes. Academy of Management Journal, 52(4), 822-846. http://dx.doi.org/10.5465/AMJ.2009.43670902

Lyles, M.A., and Easterby-Smith, M. (2003). Organizational learning and knowledge management: agendas for future research in Easterby-Smith, M. and Lyles, M.A. (Eds), Handbook of Organizational Learning and Knowledge Management, Blackwell Publishing, Oxford. manual (pp. 27-56). Plymouth, MI: Human Synergistics.

MacCarthy, B., Brabazon, P.G., \& Bramham, J. (2003). Fundamental modes of operation for mass customization. International Journal of Production Economics, $\quad 85(3), \quad 289-304$. http://dx.doi.org/10.1016/S0925-5273(03)00117-8

Marques, J. F., Allevato, E., \& Holt, S. (2008). Linking Quality Management and Emotional Intelligence to Working Spirituality. Organization Development Journal, 26, 81-88.

Mayor, J., \& Salovey, P. (1997). What is emotional intelligence? In.P. Salovey \& D.Sluyter(eds). Emotional development and emotional intelligence: Implications for educators (pp.3-31). New York: Basic Books.

McGill, M. E., Slocum, J., \& Lei, D. (1992). Management practices in learning organizations. Organizational Dynamics, 21(1), 5-17. http://dx.doi.org/10.1016/0090-2616(92)90082-X 
Meyer, J. P., \& Allen, N. J. (1990). The measurement and antecedents of affective, continuance and normative commitment to the organization. Journal of Occupational Psychology, 63(1), 1-18. http://dx.doi.org/10.1111/j.2044-8325.1990.tb00506.x

Milliman, J., Czaplewski, A \& Ferguson J. (2003). Workplace spirituality and employee work attitudes: An exploratory empirical assessment. Journal of Organizational Change Management, 16(4), 426-447. http://dx.doi.org/10.1108/09534810310484172

Milliman, J., Ferguson, J., Trickett, D., \& Condemi, B. (1999). Spirit and community at southwest airlines: An investigation of a spiritual values-based model. Journal of Organizational Change Management, 12(3), 221-233. http://dx.doi.org/10.1108/09534819910273928

Mitroff, I. I., \& Denton, E, A. (1999). Study of Spirituality in the Workplace (cover story). MIT Sloan Management Review, 40, 83-92.

Mohamed, M., Stankosky, M., \& Murray, A. (2004). Applying knowledge management principles to enhance cross-functional team performance. Journal of Knowledge Management, 8(3), 127-142. http://dx.doi.org/10.1108/13673270410541097

Nafukho, F.M., Graham, C. M., \& Muyia, M.H. (2009). Determining the relationship among organizational learning dimensions of a small-size business enterprise. Journal of European Industrial Training, 33(1), 32-51. http://dx.doi.org/10.1108/03090590910924360

Neal, J., \& Biberman. (2003). Introduction: the leading edge in research on spirituality and organizations. Journal of Organizational Change Management, 12, 345-349.

Nevis, E.C., DiBella, A.J., \& Gould, J.M. (1995). Understanding Organization as learning systems. Sloan Management Review, Winter, 73-85.

Nilsson, A., Borgstede, C.V., \& Biel, A. (2004). Willingness to accept climate change strategies: The effect of values and norms. Journal of Environmental Psychology, 24(3), 267-277. http://dx.doi.org/10.1016/j.jenvp.2004.06.002

Nur, Y. A., \& Organ, D.W. (2006). Selected organizational outcome correlates of spirituality in the workplace. Pscyhological Reports, 98(1), 111-120. http://dx.doi.org/10.2466/pr0.98.1.111-120

Pan, S. L., Pan, G., Chen, A. J., \& Hsieh, M. H. (2007). The Dynamics of implementing and managing modularity of Organizational routines during capability development: Insights from a process model. IEEE Transactions on Engineering Management, 54(4), 800-813. http://dx.doi.org/10.1109/TEM.2007.906854

Pawar, B. (2009). Some of the Recent Organizational Behavior Concepts as Precursors to Workplace Spirituality. Journal of Business Ethics, 88(2), 245-261. http://dx.doi.org/10.1007/s10551-008-9961-3

Pine II, J., Peppers, D., \& Rogers, M. (1995). Do You Want to Keep Your Customers Forever? Harvard Business Review, 73(2), 103-114.

Pine, B., Victor, B., \& Boynton, S. (1993). Making mass customization work. Harvard Business Review, 71, 108-119.

Prahalad, C. K., \& Hamel, G. (1994). Strategy as a field of study: why search for a new paradigm? Strategic Management Journal, 15(S2), 5-16. http://dx.doi.org/10.1002/smj.4250151002

Prasad, B. (2001). Total value management - a knowledge management concept for integrating TQM into concurrent product and process development. Knowledge and Process Management, 8(2), 105-122. http://dx.doi.org/10.1002/kpm.112

Prasad, S., Tata, J., \& Madan, M. (2005). Build to order supply chains in developed and developing countries. Journal of Operations Management, 23(5), 551-568. http://dx.doi.org/10.1016/j.jom.2004.10.011

Prieto, I.M., \& Revilla, E. (2006). Assessing the Impact of learning capability on Business Performance: Empirical Evidence from Spain. Management Learning, 37(4), 499-522. http://dx.doi.org/10.1177/1350507606070222

Riege, A. (2007). Actions to overcome knowledge transfer barriers in MNCs. Journal of Knowledge Management, 11(1), 48-67. http://dx.doi.org/10.1108/13673270710728231

Sanchez, R. (1995). Strategic flexibility in product competition. Strategic Management Journal, 16(S1), 135-159. http://dx.doi.org/10.1002/smj.4250160921 
Schentler, P. (2009). Implementing mass customization in the automotive industry: an analysis of requirements for procurement and procurement objects. International Journal of Automotive Technology \& Management, 9(3), 260-274. http://dx.doi.org/10.1504/IJATM.2009.027167

Schmenner, R.W., \& Tatikonda, M.V. (2005). Manufacturing process flexibility revisited. International Journal of Operations \& Production Management, 25(12), 1183-1189. http://dx.doi.org/10.1108/01443570510633585

Scott, C., \& Brown, J.S. (1999). Bridging epistemologies: the generative dance between organizational knowledge and organizational knowing. Organization Science, 10(4), 381-400. http://dx.doi.org/10.1287/orsc.10.4.381

Selladurai, R.S. (2004). Mass customization in operations management: Oxymoron or reality? Omega, 32(4),295-300. http://dx.doi.org/10.1016/j.omega.2003.11.007

Senge, P. M. (1990). The leaders New Work: Building Learning Organizations. Sloan Management Review, 32, 7-23.

Sharifuddin, S., \& Rowland, F. (2004). Knowledge management in a public organization: a study on the relationship between organizational elements and the performance of knowledge transfer. Journal of Knowledge Management, 8(2), 95-111. http://dx.doi.org/10.1108/13673270410529145

Sheep, M. L. (2006). Nurturing the Whole Person: The Effects of Workplace Spirituality in a Society of Organizations. Journal of Business Ethics, 66(4), 357-375. http://dx.doi.org/10.1007/s10551-006-0014-5

Silveira, G., Borenstein, D., \& Fogliatto, F.S. (2001). Mass customization: Literature review and research directions. International Journal of Production Economics, 72(1), 1-13. http://dx.doi.org/10.1016/S0925-5273(00)00079-7

Slater, S.F, \& Narvekar, F. J. (1995). Market orientation and the learning organization. Journal of Marketing, 59(3), 63 - 74. http://dx.doi.org/10.2307/1252120

Su, J.C., Chang, Y., \& Ferguson, M. (2005). Evaluation of postponement structures to accommodate mass customization. Journal of Operations Management, 23(3-4), 305-318. http://dx.doi.org/10.1016/j.jom.2004.10.016

Sue, H. (2002). A spiritual perspective on learning in the workplace. Journal of Managerial Psychology, 17(3), 230-243. http://dx.doi.org/10.1108/02683940210423132

Svensson, C., \& Barford, A. (2002). Limits and opportunities in mass customization for build to order SMSs. Computers in Industry, 49(1), 77-89. http://dx.doi.org/10.1016/S0166-3615(02)00060-X

Swaminathan, J.M., \& Tayur, S.H. (1998). Managing broader product lines through delayed product differentiation using vanilla boxes. Management Science, 44(12), S161-172. http://dx.doi.org/10.1287/mnsc.44.12.S161

Thyssen, J., Israelsen, P., \& Jørgensen, B. (2006). Activity-based costing as a method for assessing the economics of modularization-A case study and beyond. International Journal of Production Economics, 103(1), 252-270. http://dx.doi.org/10.1016/j.ijpe.2005.07.004

Tischler, L. (1999). The growing interest in spirituality in business: A long-term socio- economic explanation. Journal of Organizational Change Management, 12(4), 273-280. http://dx.doi.org/10.1108/09534819910282117

Tischler, L., Biberman, J., \& Altman, Y. (2007). A model for researching about spirituality in organizations. Business Renaissance Quarterly, 2, 23-39.

Tsai, W. (2002). Social structure of "Coopetition" within a multiunit organization: coordination, competition, and Intraorganizational knowledge sharing. Organization Science, 13(2), 179-190. http://dx.doi.org/10.1287/orsc.13.2.179.536

Tseng, M., \& Jiao, J. (1998). Concurrent design for mass customization. Business Process Management Journal, 4(1), 10-24. http://dx.doi.org/10.1108/14637159810200111

Ulrich, D., Von Glinow, M. A., \& Jick, T. (1993). High-Impact Learning: Building and Diffusing Learning Capability. Organizational Dynamics, 22(2), 52-66. http://dx.doi.org/10.1016/0090-2616(93)90053-4

Van Hoek, R.I. (2001). The rediscovery of postponement: a literature review and directions for research. Journal of Operations Management, 19(2), 161-184. http://dx.doi.org/10.1016/S0272-6963(00)00057-7 
Van Hoek, R.I., Voss, R.I., \& Commandeur, H.R. (1999). Restructuring European supply chain by implementing postponement strategies. Long Range Planning, 32(5), 505-518. http://dx.doi.org/10.1016/S0024-6301(99)00071-0

Voordijk, H., Meijboom, B., \& Haan, J.D. (2006). Modularity in supply chains: a multiple case study in the construction industry. International Journal of Operations \& Production Management, 26(6), 600-618. http://dx.doi.org/10.1108/01443570610666966

Wong, H., \& Eyers, D. (2011). An analytical framework for evaluating the value of enhanced customisation: an integrated operations-marketing perspective. International Journal of Production Research, 49(19), 5779-5800. http://dx.doi.org/10.1080/00207543.2010.519738

Yang, B., Burns, N., \& Backhouse, C.J. (2004). Postponement: a review and an integrated framework. International Journal of Operations \& Production Management, 24, 25-44.

Yih-Tong Sun, P., \& Scott, J.L. (2005). An investigation of barriers to knowledge transfer. Journal of Knowledge Management, 9(2), 75-90. http://dx.doi.org/10.1108/13673270510590236

Zhang, T., \& Efstathiou, J. (2006). The complexity of mass customization systems under different inventory strategies. International Journal of Computer Integrated Manufacturing, 19(5), 423-433. http://dx.doi.org/10.1080/09511920500399011

Zipkin, P. (2001). The Limits of Mass Customization. MIT Sloan Management Review, 42, 81-87.

Table 1. Studies indicating the Dimensions of Workplace Spirituality

\begin{tabular}{|c|c|}
\hline Study & Dimensions of Workplace Spirituality \\
\hline Pawar (2009) & $\begin{array}{l}\text { Organizational norms, Innerself, connectedness and } \\
\text { personal fulfillment }\end{array}$ \\
\hline Badrinarayanan \& Madhavaram (2008) & Innerself, Meaningful work and connectedness \\
\hline Gotsis \& Kortezsi (2008) & $\begin{array}{l}\text { Organizational norms, Connectedness sense of } \\
\text { transcendence and personal completeness \& enjoyment } \\
\text { at work }\end{array}$ \\
\hline Dean \& Safranski (2008) & $\begin{array}{l}\text { Organizational norms, connectedness, alignment with } \\
\text { organization value }\end{array}$ \\
\hline Ashmos \& Dunchon (2000) & Sense of inner life, meaningful work and community. \\
\hline Mitroff \& Denton (1999) & $\begin{array}{l}\text { Spirituality is a sense of connection with oneself, others } \\
\text { and workplace. }\end{array}$ \\
\hline Kolodinsky, Giacalone, \& Jurkiewicz (2008) & $\begin{array}{l}\text { Organizational norms, connectedness, personal } \\
\text { fulfillment, selfbelief }\end{array}$ \\
\hline Harrington, Preziosi \& Gooden (2001) & $\begin{array}{l}\text { Organizational norms, connectedness, alignment with } \\
\text { organizational value }\end{array}$ \\
\hline Fairholm (1996) & $\begin{array}{l}\text { Spirituality relates to inner self, and others and guides } \\
\text { individuals on the path of humanity. }\end{array}$ \\
\hline Konz \& Ryan (1999) & $\begin{array}{l}\text { Organizational norms, values, finding meaning at } \\
\text { workplace. }\end{array}$ \\
\hline Sheep (2006) & $\begin{array}{l}\text { Organizational norms, personal fulfillment, selfbelief, } \\
\text { connectedness }\end{array}$ \\
\hline
\end{tabular}


Table 2. Studies indicating the Dimensions of Organizational Learning Capability

\begin{tabular}{|l|l|}
\hline Studies & Dimensions of Organizational Learning Capabilities \\
\hline Lichtenthaler (2009) & Knowledge transfer \& creation \\
\hline Nafukho,Graham \& Muyia (2009) & $\begin{array}{l}\text { Culture, Leadership, openness in systems \& structure, } \\
\text { communication, reward \& recognition and teams }\end{array}$ \\
\hline Zipkin (2001) & Elicitation, process and logistics \\
\hline Gómez, Lorente \& Valle-Cabrera (2005) & $\begin{array}{l}\text { Managerial commitment, systems perspective, } \\
\text { openness \&experimentation, knowledge transfer and } \\
\text { integration }\end{array}$ \\
\hline Chiva, Alegre,\& Lapiedra (2005) & $\begin{array}{l}\text { Experimentation, participative decision making, } \\
\text { Dialogue, Interaction with external environment }\end{array}$ \\
\hline Gómez, Lorente, Cabrera \& Valle (2004) & $\begin{array}{l}\text { knowledge transfer and integration, learning } \\
\text { commitment; systems thinking; } \\
\text { openness and experimentation; }\end{array}$ \\
\hline DiBella, Nevis, \& Gould (1996) & $\begin{array}{l}\text { knowledge acquisition, knowledge transfer \& sharing, } \\
\text { and knowledge utilization }\end{array}$ \\
\hline Nevis,DiBella \& Gould (1995) & $\begin{array}{l}\text { Leadership \& managerial commitment, knowledge } \\
\text { scanning, continuous education, climate of openness \& } \\
\text { Operational variety }\end{array}$ \\
\hline Ulrich, Von Glinow \& Jick (1993) & Managerial commitment \& knowledge transfer \\
\hline Goh \& Richards (1997) & $\begin{array}{l}\text { Knowledge transfer, teamwork \& leadership } \\
\text { commitment }\end{array}$ \\
\hline Bhatnagar (2006) & $\begin{array}{l}\text { Strategy, organizational norms such as culture, } \\
\text { leadership, organization structures }\end{array}$ \\
\hline Crossan, Lane, \& White (1999) & $\begin{array}{l}\text { Intuiting (Experiences, Images, Interpreting } \\
\text { (Language, cognitive maps ), Integrating(Interactive } \\
\text { systems, shared understanding) and Institutionalizing } \\
\text { (norms, rules \& Procedures) }\end{array}$ \\
\hline & (19) \\
\hline
\end{tabular}




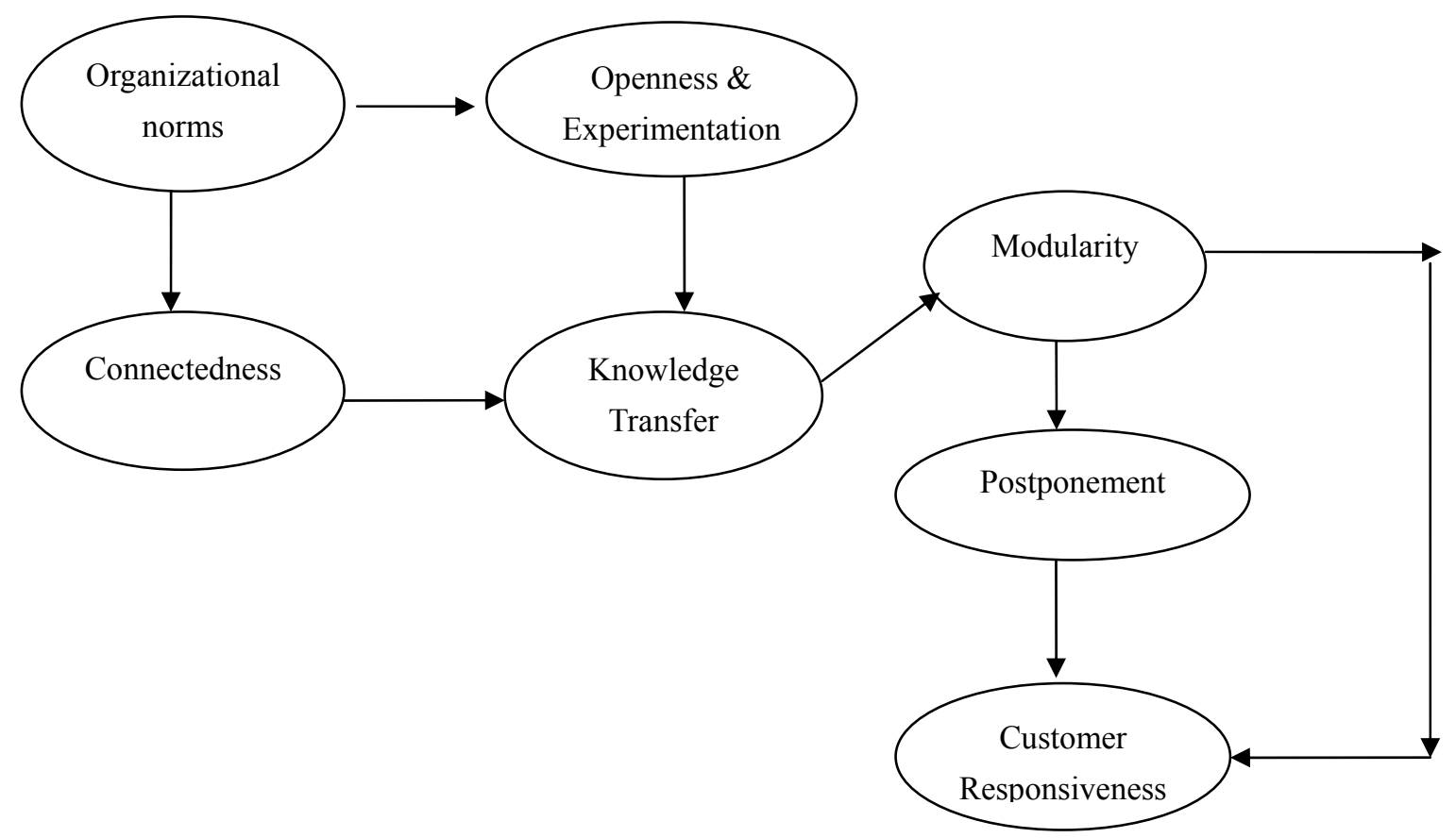

Figure 1. Integrated framework identifying the relationships between dimensions of Workplace Spirituality, Organizational learning capabilities and Mass Customization 